of him to arrange a commemorative service in the same church on the fiftieth anniversary in 1964, where many of his friends gathered to do honour to Fairfield and Marjorie. During the Benediction a golden September leaf floated through a window and slowly fell on to the altar. Nature had paid her respect.

\title{
Was Strasbourg Worthwhile?
}

\section{Bruce Campbell}

The value of the Council of Europe conference at Strasbourg on the future of the environment should be both immediate and long-term. The conference was the official 'opening' of ECY 1970. Strong speeches by Prince Bernhard of the Netherlands, Prince Philip, Prince Albert of Liège and $M$. Duhamel, the French Minister of Agriculture, emphasised the urgency of the situation that had brought together delegations from the 17 member nations, most of them led by ministers, observers from ten other countries, and representatives of some fifty international organisations.

The declaration at the end of the conference and the report of the proceedings-the fruit of over twelve hours hard drafting-have involved governments in an agreement to co-ordinate effort at all levels, and this includes the very important sphere of local authorities who, in Britain, have been so slow to take up their responsibilities under the National Parks and Access to the Countryside Act of I949. Let us hope that we shall now see some action. The Strasbourg Declaration will enable conservationists throughout Europe to put pressure on the politicians who, to do them credit, seem to be genuinely concerned.

The conference discussed as its themes four forms of impact on the natural environment: urban conglomerations, industry, agriculture and forestry, and leisure. These were presented by rapporteurs who had been studying papers submitted by the member nations and by many organisations, including UNESCO, FAO, WHO, IUCN, ICBP, the International Wildfowl Research Bureau, the World Wildlife Fund and the International Council for Hunting and Shooting, whose remarkable conservationist attitude bore tribute to years of patient persuasion by Miss Phyllis Barclay-Smith and others.

Some delegates felt that the discussions were concerned with too wide issues and that not enough was heard of wildlife conservation and its needs. But an answer to the central problem, that of the population explosion and its effects, can only be found-if indeed it existsat the highest planning level, and it seems reasonable to concentrate on this as top priority.

Two aspects which particularly interested the British delegation, youth and voluntary effort, were also not emphasised, though the final report gave both a pat on the back. But it would have been salutary to hear what the young people of Europe really think about their elders' efforts to save the environment for them. Most gratifying to the FPS was Prince Bernhard's news of the $f 250,000$ gift to the World Wildlife Fund to set up an endowment fund in the name of our Chairman, Peter Scott. 